\section{The Other Side of Zakat in Poverty Reduction: A Phenomenology Study}

\author{
Arif Widyatama \\ STIE Panca Bhakti Palu \\ arifwidyatama1o@gmail.com
}

\begin{abstract}
Andi Sabirin Baso
STIE Panca Bhakti Palu

andisabirin1@gmail.com
\end{abstract}

\section{Fathiatul Haq}

STIE Panca Bhakti Palu

Btnsasa@gmail.com
IQTISHADIA

13,1 
IQTISHADIA

13,1

78

because the most dominant sub-sectors contributing to our economic growth are non-tradable (industries that do not produce goods) which does not absorb a lot of labor. Therefore, it did not increase the real purchasing power and prosperity of the people. In addition, the poverty issue is an ongoing problem. There are other factors hampering the poverty reduction programs to work effectively. One of them is the lack of understanding about the reality of poverty itself. The poverty line is used to measure whether a person is considered poor or not (Abdul-Majeed Alaro and Alalubosa, 2019; Abdullah et al., 2015; Gamon \& Tagoranao, 2018; Kuran, 2019).

Poverty is an output obtained due to the fact that income does not comply with specified standards (Awaworyi Churchill et al., 2020; Awaworyi Churchill \& Smyth, 2020; Baloch et al., 2020; Yang et al., 2020). Basically, poverty is divided into two, absolute poverty and relative one. Someone is said to be in absolute poverty if his income or expenditure is right on the poverty line. While a person or group of people is said to be relatively poor if the expenditure or income is lower than the income or expenditure of other groups or below a certain poverty line. The high poverty line is determined by the government based on existing objective conditions. These conditions can be seen from the average level of education in the region, health, and education obtained (Awaworyi Churchill \& Smyth, 2020; Baloch et al., 2020; Chamhuri et al., 2015; Sánchez-Guevara Sánchez et al., 2020; Vera-Toscano et al., 2020; Xu et al., 2020; Yu et al., 2020).

Similarly, poverty occurs in the Palu. The economic situation of the people of Palu is quite obvious. Palu has about 31.39\% of the poor population. This number is scattered in four districts. In the District of West Palu, there are as many as 4,118 poor households, out of a total population of 87,719 inhabitants. South Palu District, has around 3,454 poor households from a total population of 88,088 inhabitants. In East Palu District, there are 2,209 poor households out of a total population of 50,634 inhabitants. In North Palu District, there are 3,595 poor households out of a total population of 29,596 inhabitants (Statistics Indonesia-Statistics in Palu, 2010). Until now, poverty is still a problem for local government. According to Statistics Indonesia data of 2018, the income of the poor in Palu was Rp473,555/capita/month. In 2015, it declined to Rp420,210/capita/month (Statistics Indonesia table for district/city poverty in 2014-2015). Thus, the illustation can be seen in the graph below: 


\section{Graph 1}

Citizen Income Poverty in Palu in 2014-2015

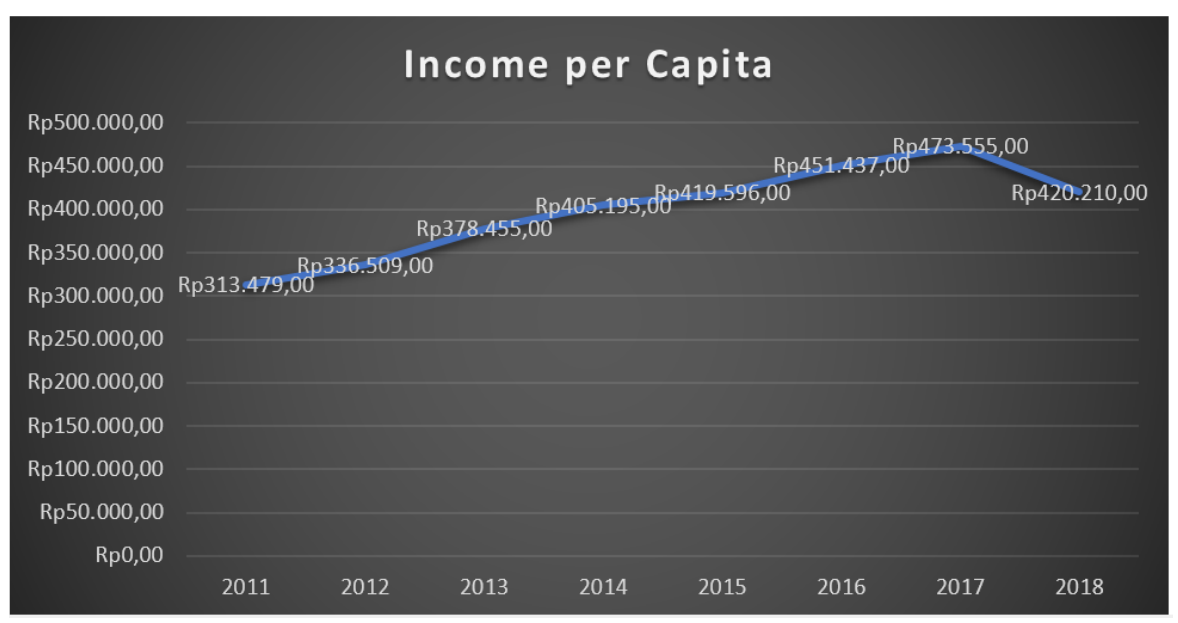

Source: Statistics Indonesia (Poverty Line in Palu, 2011-2018)
The Other Side of

Zakat in Poverty

Reduction

79

In the graph above, it can be concluded that in the past one year there was a decline in citizen income per capita of Rp. 53,345.-. This condition is not proportional to the decline in the number of poor people by 25,260 in 2018.

\section{Graph 2}

Total Poverty Population, 2011-2018

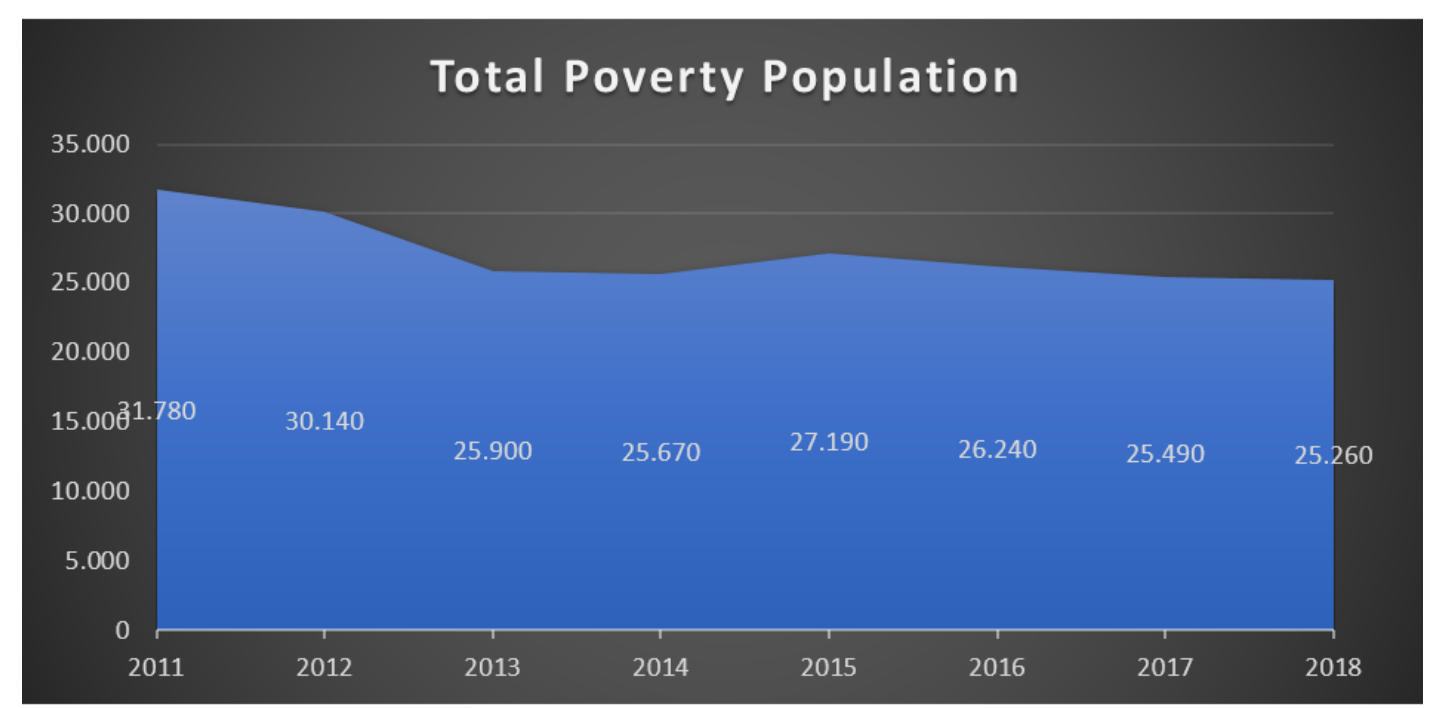

Source: Statistics Indonesia

The graph shows that the population in 2017 was 25.490 while in 2018 it was reduced to 25.260. This reduction is not significant every year. Even in 2015, there was an increase in the number of poor people to 27,190 . Whereas on the other hand, taxes have been collected and distributed in the form of 
IQTISHADIA

13,1

80

development to people, but the number of people living in poverty have not decreased from year to year. Many factors become the obstacles to reduce the level of poverty. Factors such as the unequal ownership of resources, unbalanced population capacity, and inequality of opportunities in trying and earning income will cause uneven participation in development as well. To anticipate the impact of the global economy, a number of alternative instruments are needed to be offered as a solution to the problem of poverty and other economic problems. One such instrument is Zakat, Infaq and Shadaqah (ZIS) (Abdul-Majeed Alaro and Alalubosa, 2019; Gamon and Tagoranao, 2018; Kuran, 2019; Ridwan et al., 2019).

Zakat is a predetermined right that must be issued for certain assets (Abdullah et al., 2015; Ahmad et al., 2015; Alim, 2015; Ambrose et al., 2015) Infaq is issuing assets that include zakat and non- zakat. Meanwhile, Shadaqah is all gifts with which we expect rewards from Allah SWT. Gifts (al 'athiyah) can be interpreted broadly, both gifts in the form of assets and gifts in the form of an attitude or good deeds (Burde et al., 2015; Skoufias et al., 2020).

The advantages of the Islamic system are that besides encouraging its people to seek the highest income (economic growth), Islam also encourages and provides a just distribution of wealth as zakat, infaq and shadaqah. In this case, Islam treats poverty directly to the root of the problem, which is to treat human greed. According to islamic perspective the problem with the rich (muzakki) has to be solved first. With zakat, infaq and shadaqah, they can contribute to reduce poverty and also cleanse themselves from inner poverty such as greed. Islam cleanses them from spiritual poverty that is called ruhiyah, and hopefully will spread to the object of zakat, infaq, and shadaqah (Abdul-Majeed Alaro \& Alalubosa, 2019; Ahmad et al., 2015; Gamon \& Tagoranao, 2018; Jamal et al., 2019).

Research conducted by Ahmad et al. (2015); Alim, (2015); Aufseeser, (2020) examined how zakat was distributed to mustahiq while the purpose of this study is to understand the other side of zakat in poverty reduction that occurs in Palu.

\section{LITERATURE REVIEW}

Zakat is a way of alleviating poverty by disbursing some money gained from the rich to the poor to be used for productive activities. Zakat is related to the principle of justice. The most fundamental problem is the issue of economic justice on how people who do not get sustenance can get access to improve 
their welfare. Therefore, in the framework of alleviating poverty, there must be efforts that genuinely represent the responsibility to uphold justice that we start from economic prosperity. From the description above, there is a vital vision contained in the teachings of zakat, which is to uphold social justice for the benefit of many people in their social life, especially the weak and powerless. Therefore, regulating zakat correctly and properly is needed to ensure no life inequality and social injustice between the able and the incapable (Abdul-Majeed Alaro \& Alalubosa, 2019; Gamon \& Tagoranao, 2018; Kuran, 2019; Muhtadi Ridwan et al., 2019).

The existing zakat system so far have not been able to see the real root of the problem, or in other words, they do not go directly to the heart of the conflict. One reason is that the perspective used in the concept of zakat and the existing zakat system is a formalistic religious view rather than substantivity, meaning that so far zakat has only been seen as an act of rationality and mere ceremonial (Kamla \& Haque, 2019; Khalid et al., 2015; Kuran, 2019; Mahat et al., 2015). Zakat is seen as worship that only has personal and individual dimensions; it does not touch the social aspect, so that zakat does not affect any social life. Meanwhile, the social reality that occurs from time to time keeps changing and developing as it is today. Problems that arise also develop, which are more diverse and complex, including those related to zakat as an instrument to uphold social justice and the benefit of the people. The problems that arise in the present may not have been known by fiqh experts in the past (Alim, 2015; Ambrose et al., 2015; Brown \& James, 2020).

\section{RESEARCH METHOD}

This study uses qualitative research because researchers become key instruments in extracting information obtained from the informants. The data collection is by triangulation, data analysis is inductive and the results of research emphasize the meaning rather than generalization. Qualitative research using a phenomenology approach is considered the most suitable to be used in this study which aims to see the reality while understanding the meaning of what, why and how a phenomenon occurs in accounting practices. This research is more inclined to use interpretive paradigms which assume that science is not based on standard laws and procedures but a deep understanding of reality as it is.

Research is carried out in natural situations so that there are no limits in interpreting or understanding the activities being studied. Understanding
The Other Side of

Zakat in Poverty

Reduction

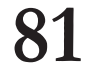


IQTISHADIA

13,1

82

of an event depends on who is interpreting, time, situation, interests or purpose of reading, knowledge, habits, experience, and other backgrounds. In this case, researchers want to understand the meaning of zakat for informants, as well as the role of zakat for those living in poverty. There are 3 people functioning as informants in this study. The first informant named Siti Khadijah was originally a beggar and then when given assistance she could build a cake trading business. The second one named Emmy Dile, a mother who initially had a foodstall which was later developed a "lalampa" sale. The last one named Wani Abd Hafiz who had a laundry business then develops the business by making kiosks. The results of interviews with the three informants will be further analyzed to become evidence to support the truth in revealing the value contained in the accounting business practices. The results of research on accounting practices of business laundry cannot be generalized as a result of research with a positive paradigm because the phenomenological approach emphasizes subjectivity as scientific truth.

Data collection techniques in this study, include: (a) a preliminary survey by digging information through articles, the internet, and print media about MSMEs; (b) a literature survey in the form of activities to collect and study finished data obtained from books, journals and legislation adjusted to the supporting theories ; (c) field data collection, namely the results of observations, interviews, and documentation conducted by researchers on the three informants and then the data are analyzed to answer the research questions.

\section{RESUTLTS AND DISCUSSION}

Zakat is one of the pillars of Islam that must be implemented. The obligation of zakat is the same as the obligation of prayer. In the Qur'an, there are 32 verses that command prayer and zakat simultaneously. According to the term, zakat is the giving of certain assets to those who are entitled as compulsory worship to Allah. People awareness in understanding the law of paying zakat is very important. With the awareness, an increase in zakat payments through $\mathrm{BAZ}$ will happen. However, if the people do not understand the law of paying zakat, the potential of zakat cannot be realized properly. The function of zakat should be able to reduce the poverty level of an area, because zakat has different functions from taxes that focuses on infrastructure development in an area. Instead, zakat focuses on those groups that need it. Thus, hopefully the existence of zakat can reduce poverty. Poverty is a multi-dimensional problem that requires multi-dimensional intervention policies and programs 
so that individual welfare increases. There are two ways to measure poverty, the first approach views poverty in an absolute measure manifested as poverty lines, points, or limits. Individuals or people who are unable to get out of these measures are classified as poor. The measure includes the level of income, expenditure or consumption, or calories of a person or family in a certain time and things that are equal to that size. This approach is easier to apply because it is only compared to the desired limit. Secondly, approaches that look at poverty as a measure that is influenced by other measures related to proportion or distribution. For examples, the poverty line is the lowest $20 \%$ of income, the median of income distribution and others.

\section{Table 1}

Poverty Line and Number of Poor People in Palu Municipality, 2011-2015

\begin{tabular}{cccc} 
& & \multicolumn{2}{c}{ Number of Poor People } \\
\hline Year & Poverty Line (rupiah) & Total & Percentage \\
$(1)$ & $(2)$ & $(3)$ & $(4)$ \\
\hline 2011 & 313479 & 31784 & \\
\hline 2012 & 336509 & 30143 & $-5.44 \%$ \\
\hline 2013 & 378455 & 25905 & $-16.37 \%$ \\
\hline 2014 & 405195 & 25660 & $-0.90 \%$ \\
\hline 2015 & 416596 & 27.190 & $5.59 \%$ \\
\hline 2016 & 451437 & 26,240 & $-3.62 \%$ \\
\hline 2017 & 473,555 & 25,490 & $-2.94 \%$ \\
\hline 2018 & 420210 & 25,260 & $-0.91 \%$ \\
\hline
\end{tabular}

Source: Statistics Indonesia, 2020

Based on Table 1, it can be seen that each year there is an increase in the poverty line and a significant decrease in the number of poor people with a percentage of up to $7.05 \%$. As can be seen, in 2011 the poverty line or can be called the income of the poor in Palu was Rp. 313,479 with a number of poor populations of 31,784 inhabitants. In 2012, the income of the poor increased to Rp. 336,509 with the number of poor people declining to 30,143. In 2013 and 2014, the income of the poor increased from Rp 378,455 to Rp 405,195 as did the number of poor people from 25,905 to 25,660. Although in 2015 there was an increase in the income of the poor population of Rp 416,596, the population of the poor still increase from 25,660 people to 27,190 people.
The Other Side of Zakat in Poverty Reduction 
IQTISHADIA

13,1

84

Thus in 2016, the number of poor people in Palu declined again. In 2017 and 2018, the number also decreased respectively to 25,490 and 25,260. Thus, it can be said that the number of poor people in Palu fluctuated and can be seen in the following table:

\section{Table 2}

Number of Poor People by Regency/City in Central Sulawesi Province (thousand), 2013-2018

\begin{tabular}{lcccccc}
\multicolumn{1}{c}{ City/District } & 2013 & 2014 & 2015 & 2016 & 2017 & 2018 \\
\hline Banggai Kepulauan & 29,400 & 28,410 & 18,570 & 18,720 & 18,560 & 18,382 \\
\hline Banggai & 33,800 & 32,644 & 34,740 & 33,970 & 33,500 & 33,725 \\
\hline Morowali & 35,400 & 34,225 & 17,790 & 17,360 & 16,990 & 17,034 \\
\hline Poso & 41,300 & 39,913 & 42,640 & 42,230 & 41,880 & 41,747 \\
\hline Donggala & 49,600 & 47,933 & 54,170 & 55,690 & 54,440 & 54,281 \\
\hline Toli-Toli & 30,700 & 29,644 & 30,700 & 30,680 & 30,640 & 31,795 \\
\hline Buol & 21,600 & 20,878 & 24,310 & 25,270 & 25,760 & 25,397 \\
\hline Parigi Moutong & 75,500 & 72,947 & 82,610 & 82,380 & 82,880 & 83,663 \\
\hline Tojo Una-Una & 29,700 & 28,743 & 27,620 & 27,620 & 27,300 & 27,777 \\
\hline Sigi & 27,600 & 26,682 & 29,140 & 29,550 & 29,550 & 29,776 \\
\hline Banggai Laut & - & & 12,330 & 11,590 & 11,630 & 11,970 \\
\hline Morowali Utara & - & & 19,810 & 19,220 & 19,250 & 19,401 \\
\hline Kota Palu & 25,900 & 25,041 & 27,190 & 26,240 & 25,490 & 25,263
\end{tabular}

Source: Statistics Indonesia, 2020

Based on Table 2, it can be seen that the number of poor people fluctuated. In 2013, the number of poor people was 25,900 inhabitants. In 2014, it decreased to 25,660 inhabitants. Afterwards, an increase happened again in 2015 to be 27,190 inhabitants and in 2016 it decreased to 26,240 inhabitants. In 2017 and 2018, it also declined to 25,490 and 25,263. Thus, it was concluded that even though the income of the population increased the number of poor people could still increase and be confined over time.

\section{The Concept of Zakat as Methods of Poverty Reduction}

One of the most important instruments in Islam to overcome poverty is zakat. Zakat is a religious instrument that helps individuals in society to help 
the needy and poor population who are unable to help themselves. Zakat is one step to reduce poverty that occurs in the community (Abdul-Majeed Alaro \& Alalubosa, 2019; Abdullah et al., 2015; Alim, 2015; Kamla \& Haque, 2019; Khalid et al., 2015; Kuran, 2019; Mahat et al., 2015; Morris et al., 2020)we specifically highlight the role of internal collaborators associated with AAOIFI like Islamic Financial Institutions (IFIs. The impact of zakat on poverty reduction is significant and it runs automatically (built-in) in the Islamic system. The general public only knows that the purpose of zakat is to reduce poverty and help the poor, without knowing the picture clearly. Islam views poverty as one thing that can endanger aqidah, morals, logical thinking, family and society.

There are many countries that are now using zakat as a means of poverty reduction, Egypt and Algeria for example. In both countries, zakat is optimally netted and managed for various poverty reduction programs. The existence of an order of zakat is actually intended so that the poverty level does not increase, or at least the poverty level can be minimized. The existence of the command of zakat also makes it clear that Islam teaches economic equality, so that wealth does not dwell on the elite only so that the gap between the poor and the rich can be narrowed.

Based on the results of interviews obtained from Warni (2018) that the role of zakat given can help reduce poverty by increasing income from the proceeds of capital obtained,

"I heard about BAZNAS from my friend, he told me BAZNAS can help my business. Firstly, I started trial and error on how to submit the application. The form for donation that I need had been sent, it was returned again, but at some time, there was at new year BAZNAS contacted me again and they gave me Rp1,500,00o. This help grew to buy materials, a lot of goods and can help laundry businesses as well “(Warni, 2018).

But it needs to be understood that there is a meaning obtained from the results of the interview. When a donation like zakat is given to Warni, the business that was previously only laundry can be developed into a food stall. The zakat system provided is different from directly-given cash provided by the government in the sense that zakat is able to reduce poverty by increasing people's income.
The Other Side of Zakat in Poverty Reduction 
IQTISHADIA

"I will not lie, I used to work as a beggar. The most important thing, I did not steal other people's things. Then, I got information from a friend (neighbor) that BAZNAS can help me. Therefore, I began to prepare the documents needed to submit a request for funds. Like a family card, Poor Certificate and photocopy of KTP. Then, I was told to wait for 1 month to get further information. After that, I was notified that my document was accepted and approved. BAZNAS provided me with a fund of Rp1,500,000. I bought the used plates, cups and trays. I managed these as the basis for making cakes. Alhamdulillah, until this day my business has grown. In addition to getting profits, some of the money is set aside to be saved as well. Thanks to the help by BAZNAS, I no longer beg as my daily basis job".

Zakat which gradually turns into a kind of temporary activity, which is collected at the same time as zakat fitrah. As a result, the utilization of zakat should take the form of consumptive relief of the temporary burden given once a year, and there is no attempt to free them to become independent. Thus, the burden on the lives of needy and poor people will only disappear temporarily and subsequently will return to poverty(Ambrose et al., 2015; Aufseeser, 2020; Baloch et al., 2020; Hassan et al., 2019; Hassan \& Aliyu, 2018; Heyneman \& Lee, 2016; Imam \& Kpodar, 2016; Jaime-Castillo et al., 2016).

Therefore, zakat is very appropriate in improving consumption, production and distribution patterns in the context of the welfare of the people. Because, one of the biggest crimes of capitalism is the control and ownership of production resources by a handful of people who are economically benefited, thus, this has implications for their neglect of people who are less able and economically unfortunate. Thus, zakat will be able to increase production, this is done to meet the high demand for goods. In order to optimize the influence of zakat, two approaches should be used, a partial approach and a structural approach.

Similar results from interviews conducted with Ms. Emma (2018)

"I know abou BAZNAS from staff's directly. Then, I prepared the necessary requirements directly such as business license, KTP and Family Card. After the documents were approved, I was given a fund of Rp. 750,000. Before, I owned a cake business, my job was to stock the cafeteria at school. Now, I have a "lalampa" cake business that can be ordered for events. Alhamdulillah, I have received many or- 
ders, especially when fast break at ramadhan. Now my business has good development, I thank to the funds from BAZNAS"

From the interview, it can be explained that a system for allocating zakat to the people in need is needed so that they can overcome poverty with various steps and strategies. The role of giving alms can be done from the beginning to overcome the poverty that surrounds our society is to create an economic order that allows the birth of a just distribution system, to encourage the birth of concern for the rich towards the needy, dhu'afa 'and mustadh 'afin. One form of concerns for the rich is his willingness to pay zakat and shadaqah.

Zakat is infaq or the expenditure of assets that is mandatory, while Sadaqah is sunnah. In an economic context, both are forms of distribution of wealth among human beings. Therefore, zakat has a very strategic function in the context of the economic system, as one of the instruments of wealth distribution (Lubis et al., 2017; Luo et al., 2020; Mahat et al., 2015; Marzano et al., 2020) today, waqf institutions are reported to have merely mild contribution particularly to the improvement of Muslim community in Malaysia. Based on scholarly reviews, several explanations and suggestions for improvement were discussed and offered to rectify the polemical situation. One of the issues highlighted was on the low level of understanding among the local Muslim on the concept of waqf. The main objective of the present paper is to propose a small scale waqf project named as "Mikro-Waqaf: Payung Teduhan Ilmu" (MWPTI. Meanwhile, the distribution of zakat has changed. Even as time goes on, the function and role of zakat in the economy began to shrink and is even marginalized and considered as a ritual of worship alone. There is a dysfunction of the function of zakat as a social stabilization, even then some people think that zakat is only an obligation and there is no empathy and social solidarity to help each other.

This has implications for the continuity of zakat which gradually turns into a kind of temporary activity, which is collected at the same time as zakat fitrah. As a result, the utilization of zakat should take the form of consumptive relief of the temporary burden given once a year, and there is no attempt to free them to become independent. As a result, the burden on the lives of needy and poor people will only disappear for a while and then will return to being needy and poor again (Jin et al., 2020; Kamla \& Alsoufi, 2015; Kamla \& Haque, 2019; Khalid et al., 2015; Kuran, 2019).

Therefore, zakat is very appropriate in improving consumption, production and distribution patterns in the context of the welfare of the
The Other Side of

Zakat in Poverty

Reduction 
IQTISHADIA

13,1

88

people. One of the biggest crimes of capitalism is the control and ownership of production resources by a handful of people who are economically benefited. This has implications such as the neglect of people who are less able and economically unfortunate. Thus, zakat will be able to increase production by meeting the high demand for goods. In order to optimize the influence of zakat, two approaches should be used, namely a partial approach and a structural approach (Mercier et al., 2020; Michalopoulos et al., 2016; Muhammad \& Saad, 2016; Nusrate Aziz \& Mohamad, 2016; Osman et al., 2015).

Based on the information from the 3 informants above, we can conclude that with the help of BAZNAS, zakat can change a family from being unable to become able and provide employment opportunities for the community. When described in the form of a BAZNAS donation scheme, it can change a family that is unable to become able as follows:

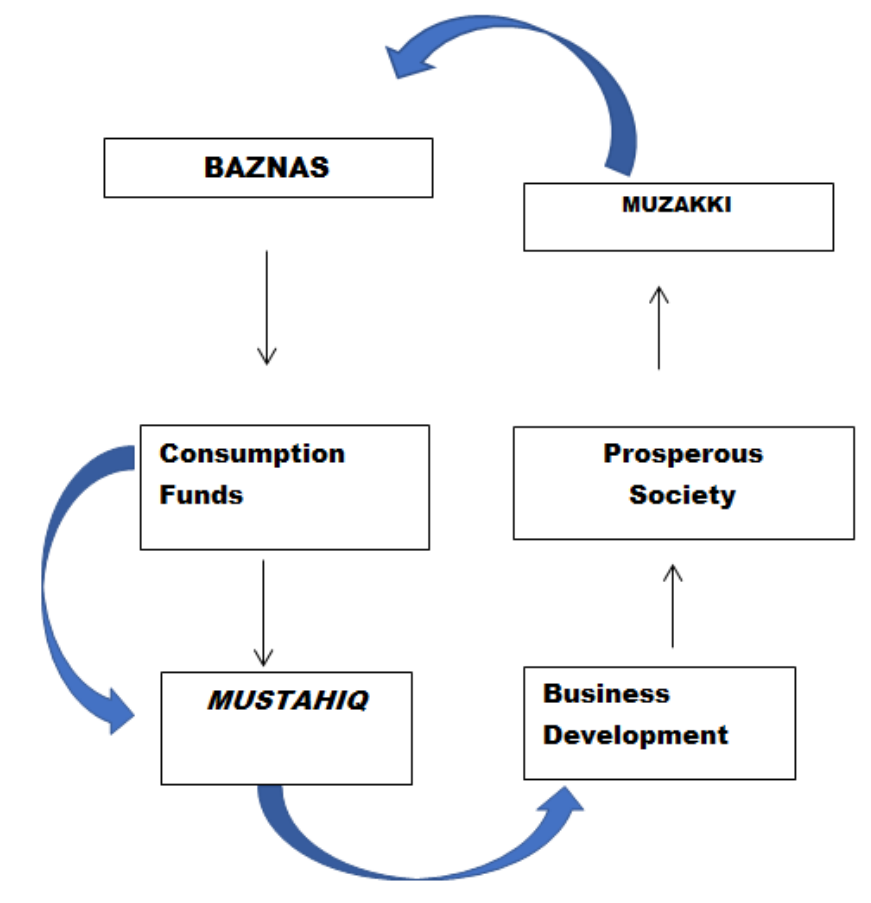

The scheme explains that donation and development to the community, or results that can be taken, is the role and contribution of BAZNAS to the community, especially Muslims, that not only in quantitative measures, but also qualitative measures, especially the role of BAZNAS in disseminating zakat values in the community. The values of faith and piety to Allah SWT, work ethic, work ethics in seeking halal and good fortune, as well as the values of zakat related to character building as human beings who must benefit others. The impacts that will occur by being given to the 8 asnaf above can help morally and in the form of assistance aimed at helping everyday life 
(Abdul-Majeed Alaro \& Alalubosa, 2019; Gamon \& Tagoranao, 2018; Kuran, 2019; M. Ridwan et al., 019).

BAZNAS is a body that is very helpful to the community with significant segment and large population. It is even better if it is used for handling in business funding, as in the program to fund the business, to be improved in giving to Mustahiq. BAZNAS carried out poverty reduction if there is a shared awareness of fellow human beings and creativity in developing businesses so that every person who is in need can have work.

\section{CONCLUSION}

Zakat is different scheme from the tax. The zakat system has many differences with taxes. When the tax is used for the public interest, Zakat collected from Muzakki will be given directly for the benefit of Mustahiq so that the allocation is mostly for the benefit of the poor. People who receive zakat are greatly helped and successfully "waken up" from adversity when getting the zakat. The given zakat has a blessing magnet so that the given zakat becomes the first step to increase income and ultimately reduce poverty. The system built by BAZNAS as the management of zakat becomes an important way in the success of the zakat.

BAZNAS management system must be carried out in a professional, transparent and accountable manner and aims at eradicating poverty and unemployment in Palu with a cultural approach based on faith. Besides, it helps the poor in community. One of the goals is to create some of muzakki and awareness of helping each other.

The research offers some new insights on how zakat can substitute taxes. It can be allocated to the needy in order to be used productively. Another contribution of the research can be found in the research methodology. This research discussess zakat from the point of view of the muzakki, the mustahiq and Baznas as the parties involved in zakat management.

\section{LIMITATION}

The limitation of this research lies in the types of zakat that are not discussed thoroughly. Research conducted by Ahmad et al. (2015); Alim, (2015); Aufseeser, (2020) examined how zakat was distributed to mustahiq while the purpose of this study is to understand the other side of zakat in poverty reduction that occurs in Palu. Future studies should interpret aspects of productive zakat by looking at the benefits obtained. 
IQTISHADIA

13,1

90

\section{Reference}

Abdul-Majeed Alaro, A. R., \& Alalubosa, A. H. (2019). Potential of Sharı̄ah compliant microfinance in alleviating poverty in Nigeria: A lesson from Bangladesh. International Journal of Islamic and Middle Eastern Finance and Management, 12(1), 115-129. https://doi.org/10.1108/ IMEFM-01-2017-0021.

Abdullah, N., Derus, A. M., \& Al-Malkawi, H. A. N. (2015). The effectiveness of zakat in alleviating poverty and inequalities a measurement using a newly developed technique. Humanomics, 31(3), 314-329. https:// doi.org/10.1108/H-02-2014-0016.

Ahmad, R. A. R., Othman, A. M. A., \& Salleh, M. S. (2015). Assessing the Satisfaction Level of Zakat Recipients Towards Zakat Management. Procedia Economics and Finance, 31(15), 140-151. https://doi. org/10.1016/s2212-5671(15)01141-7.

Alim, M. N. (2015). Utilization and Accounting of Zakat for Productive Purposes in Indonesia: A Review. Procedia - Social and Behavioral Sciences, 211(September), 232-236. https://doi.org/10.1016/j. sbspro.2015.11.028.

Ambrose, A. H. A. A., Aslam, M., \& Hanafi, H. (2015). The Possible Role of Waqf in Ensuring a Sustainable Malaysian Federal Government Debt. Procedia Economics and Finance, 31(15), 333-345. https://doi. org/10.1016/s2212-5671(15)01205-8.

Aufseeser, D. (2020). Towards a relational understanding of child poverty: Care and adverse inclusion among street-affiliated children in Peru. Geoforum, 114(March 2019), 10-18. https://doi.org/10.1016/j. geoforum.2020.05.016.

Awaworyi Churchill, S., \& Smyth, R. (2020). Ethnic diversity, energy poverty and the mediating role of trust: Evidence from household panel data for Australia1. Energy Economics, 86, 104663. https://doi.org/10.1016/j. eneco.2020.104663.

Awaworyi Churchill, S., Smyth, R., \& Farrell, L. (2020). Fuel poverty and subjective wellbeing. Energy Economics, 86, 104650. https://doi. org/10.1016/j.eneco.2019.104650.

Badan Pusat Statistik. (2020). Pertumbuhan Ekonomi Indonesia Triwulan IV-2019. Www.Bps.Go.Id, 17/o2/Th. XXIV, 1-12. https://www.bps. go.id/pressrelease/2020/02/05/1755/ekonomi-indonesia-2019tumbuh-5-02-persen.html. 
Baloch, M. A., Danish, Khan, S. U. D., \& Ulucak, Z. Ş. (2020). Poverty and vulnerability of environmental degradation in Sub-Saharan African countries: what causes what? Structural Change and Economic Dynamics, 54, 143-149. https://doi.org/10.1016/j. strueco.2020.04.007.

Brown, P., \& James, D. (2020). Educational expansion, poverty reduction and social mobility: Reframing the debate. International Journal of Educational Research, 10o(December 2019), 101537. https://doi. org/10.1016/j.ijer.2020.101537.

Burde, D., Middleton, J. A., \& Wahl, R. (2015). Islamic studies as early childhood education in countries affected by conflict: The role of mosque schools in remote Afghan villages. International Journal of Educational Development, 41, 70-79. https://doi.org/10.1016/j. ijedudev.2014.10.005.

Chamhuri, N. H., Hamdan, H., Ahmah, P., \& Ismail, F. (2015). Conceptual Framework of Public Participation in Ensuring Quality of Life of the Urban Poor in Malaysia. Procedia - Social and Behavioral Sciences, 168, 349-356. https://doi.org/10.1016/j.sbspro.2014.10.240.

Gamon, A. D., \& Tagoranao, M. S. (2018). Zakat and poverty alleviation in a secular state: The case of muslim minorities in the Philippines. Studia Islamika, 25(1), 97-133. https://doi.org/10.15408/sdi.v25i1.5969.

Hassan, M. K., \& Aliyu, S. (2018). A contemporary survey of islamic banking literature. Journal of Financial Stability, 34, 12-43. https://doi. org/10.1016/j.jfs.2017.11.006.

Hassan, M. K., Aliyu, S., Huda, M., \& Rashid, M. (2019). A survey on Islamic Finance and accounting standards. Borsa Istanbul Review, 19, S1S13. https://doi.org/10.1016/j.bir.2019.07.006.

Heyneman, S. P., \& Lee, B. (2016). International organizations and the future of education assistance. International Journal of Educational Development, 48, 9-22. https://doi.org/10.1016/j. ijedudev.2015.11.009.

Imam, P., \& Kpodar, K. (2016). Islamic banking: Good for growth? Economic Modelling, 59, 387-401. https://doi.org/10.1016/j. econmod.2016.08.004.

Jaime-Castillo, A. M., Fernández, J. J., Valiente, C., \& Mayrl, D. (2016). Collective religiosity and the gender gap in attitudes towards economic redistribution in 86 countries, 1990-2008. Social Science Research, 57, 17-30. https://doi.org/10.1016/j.ssresearch.2016.01.009.
The Other Side of

Zakat in Poverty

Reduction

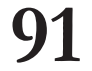


IQTISHADIA

13,1

92

Jamal, A., Yaccob, A., Bartikowski, B., \& Slater, S. (2019). Motivations to donate: Exploring the role of religiousness in charitable donations. Journal of Business Research, 103(February), 319-327. https://doi. org/10.1016/j.jbusres.2019.01.064.

Jin, G., Guo, B., \& Deng, X. (2020). Is there a decoupling relationship between $\mathrm{CO} 2$ emission reduction and poverty alleviation in China? Technological Forecasting and Social Change, 151(December 2019), 119856. https://doi.org/10.1016/j.techfore.2019.119856.

Kamla, R., \& Alsoufi, R. (2015). Critical Muslim Intellectuals' discourse and the issue of "Interest" (ribā): Implications for Islamic accounting and banking. Accounting Forum, 39(2), 140-154. https://doi. org/10.1016/j.accfor.2015.02.002.

Kamla, R., \& Haque, F. (2019). Islamic accounting, neo-imperialism and identity staging: The Accounting and Auditing Organization for Islamic Financial Institutions. Critical Perspectives on Accounting, 63, 102000. https://doi.org/10.1016/j.cpa.2017.06.001.

Khalid, A., Nyborg, I., \& Khattak, B. N. (2015). Whose property whose authority? Gendering the legal and customary practices in ownership and access to land: A case of Swat, Pakistan. Journal of Rural Studies, 41, 47-58. https://doi.org/10.1016/j.jrurstud.2015.07.004.

Kuran, T. (2019). Zakat: Islam's missed opportunity to limit predatory taxation. Public Choice, April. https://doi.org/10.1007/s11127-019oo663-x.

Lubis, A. R., Fachrizal, F., \& Lubis, M. (2017). The Effect of Social Media to Cultural Homecoming Tradition of Computer Students in Medan. Procedia Computer Science, 124, 423-428. https://doi.org/10.1016/j. procs.2017.12.173.

Luo, C., Li, S., \& Sicular, T. (2020). The long-term evolution of national income inequality and rural poverty in China. China Economic Review, 62(September 2019), 101465. https://doi.org/10.1016/j. chieco.2020.101465.

Mahat, M. A., Jaaffar, M. Y., \& Rasool, M. S. A. (2015). Potential of MicroWaqf as an Inclusive Strategy for Development of a Nation. Procedia Economics and Finance, 31(15), 294-302. https://doi.org/10.1016/ s2212-5671(15)01193-4.

Marzano, A., Viza, E., \& Cano, M. (2020). DigiCAP: Towards digitalization for empowerment and capacity building of handcraft developments in Sub-Saharan Africa. Procedia CIRP, 88, 179-184. https://doi. org/10.1016/j.procir.2020.05.032. 
Mercier, M., Ngenzebuke, R. L., \& Verwimp, P. (2020). Violence exposure and poverty: Evidence from the Burundi civil war. Journal of Comparative Economics, October 2018, 1-19. https://doi.org/10.1016/j. jce.2020.04.005.

Michalopoulos, S., Naghavi, A., \& Prarolo, G. (2016). Islam, inequality and pre-industrial comparative development. Journal of Development Economics, 120, 86-98. https://doi.org/10.1016/j. jdeveco.2016.01.002.

Morris, M. H., Santos, S. C., \& Neumeyer, X. (2020). Entrepreneurship as a solution to poverty in developed economies. Business Horizons, 63(3), 377-390. https://doi.org/10.1016/j.bushor.2020.01.010.

Muhammad, S. A., \& Saad, R. A.-J. (2016). Moderating Effect of Attitude toward Zakat Payment on the Relationship between Moral Reasoning and Intention to Pay Zakat. Procedia - Social and Behavioral Sciences, 219, 520-527. https://doi.org/10.1016/j.sbspro.2016.05.029

Nusrate Aziz, M., \& Mohamad, O. Bin. (2016). Islamic social business to alleviate poverty and social inequality. International Journal of Social Economics, 43(6), 573-592. https://doi.org/10.1108/IJSE-06-20140129.

Osman, M. M., Bachok, S., Muslim, S. A., \& Bakri, N. I. M. (2015). Unemployment Issues and Problems in Kinta, Manjung and Kuala Kangsar, Perak, Malaysia. Procedia - Social and Behavioral Sciences, 168, 389-399. https://doi.org/10.1016/j.sbspro.2014.10.245.

Ridwan, M., Andriyanto, I., \& Suharso, P. (2019). The BAZNAS Strategy in Coastal Region Economic Empowerment. IOP Conference Series: Earth and Environmental Science, 246(1). https://doi. org/10.1088/1755-1315/246/1/012073.

Ridwan, Muhtadi, Asnawi, N., \& Sutikno, S. (2019). Zakat collection and distribution system and its impact on the economy of Indonesia. Uncertain Supply Chain Management, 7, 589-598. https://doi. org/10.5267/j.uscm.2019.6.001.

Sánchez-Guevara Sánchez, C., Sanz Fernández, A., Núñez Peiró, M., \& Gómez Muñoz, G. (2020). Energy poverty in Madrid: Data exploitation at the city and district level. Energy Policy, 144(March 2019). https://doi. org/10.1016/j.enpol.2020.111653.

Skoufias, E., Diamond, A., Vinha, K., Gill, M., \& Dellepiane, M. R. (2020). Estimating poverty rates in subnational populations of interest: An assessment of the Simple Poverty Scorecard. World Development, 129, 104887. https://doi.org/10.1016/j.worlddev.2020.104887.
The Other Side of Zakat in Poverty Reduction 
IQTISHADIA

13,1

94

Vera-Toscano, E., Shucksmith, M., \& Brown, D. L. (2020). Poverty dynamics in Rural Britain 1991-2008: Did Labour's social policy reforms make a difference? Journal of Rural Studies, 75(August 2019), 216-228. https://doi.org/10.1016/j.jrurstud.2020.02.003.

Xu, J., Song, J., Li, B., Liu, D., Wei, D., \& Cao, X. (2020). Do settlements isolation and land use changes affect poverty? Evidence from a mountainous province of China. Journal of Rural Studies, 76(135), 163-172. https://doi.org/10.1016/j.jrurstud.2020.04.018.

Yang, Y., de Sherbinin, A., \& Liu, Y. (2020). China's poverty alleviation resettlement: Progress, problems and solutions. Habitat International, 98(March 2019), 102135. https://doi.org/10.1016/j. habitatint.2020.102135.

Yu, D., Caughy, M. O. B., Smith, E. P., Oshri, A., \& Owen, M. T. (2020). Severe poverty and growth in behavioral self-regulation: The mediating role of parenting. Journal of Applied Developmental Psychology, 68(July 2019), 101135. https://doi.org/10.1016/j.appdev.2020.101135. 